\title{
Measurement of the degradation of abandoned turf
}

\author{
Krisztina Varga - István Csízi \\ University of Debrecen, Institutes for Agricultural Research and Educational Farm, Research Institute Karcag \\ vargakrisztina@agr.unideb.hu
}

\begin{abstract}
SUMMARY
With the decreasing number of grazing livestock in Hungary, the role of the turf cultivation is also significantly decreasing. The proportion of the under-and non-utilized turf is increasing. In the research conduced at the University of Debrecen, IAREF Research Institute Karcag, we studied four types of turf utilization in three replicates on a salt field with timothy grass. We determined the flora composition of the experimental area, measured the soil moisture and the carbon-dioxide content of the soil.
\end{abstract}

Keywords: abandoned turf, coenology, carbon-dioxide emission, soil moisture

\section{INTRODUCTION}

Turf is one of the production systems whose significance and judgement have changed a lot in the recent decades. On the Earth the total area of the turf exceeds the territory of fields and deserts altogether. Animal products indirectly from the turf are very important on several parts of the world. Until the XIX. century this was so in Hungary, too. Since then, the size and the standard of Hungarian turf utilization has gradually been decreasing. In the XIX. century turf with the best soil features was cracked for fields. From the middle of the XX. century the ancient shepherd order began to split up. After the regime change animal products from the pasture lost their markets and another new phenomenon decreased the number of the employees in livestock- breeding: this job requires work on 365 days of the year and this lifestyle no longer suits into the XIX. century. Environmentally programmes in connection with the turf provide extra income to the farmers and causes extensification of this branch. Consequences of these events are that useful livestock species are constantly disappearing. On the under-, and non-utilized turf investigation of changes in flora structure and topsoil is the aim of our study.

\section{Literature background}

15 percentage ( 799.3 thousand ha) of the agriculture area of Hungary is (KSH, 2017), which could mean enormous fodder base. In conditional, because the actual situation is influenced by the following factors: turf is a serving branch of raising livestock with grazing. With the loss of its profitability and prestige, this branch is also in crisis (Vinczeffy, 1993), the domestic turf areas are gradually decreasing (Harcsa et al., 2009). Turf with a lot of species and close to nature is drastically decreasing because of plantation tree production and building (Vinczeffy, 1993). Turf utilization is largely affected by the frequent extreme weather conditions. Turf with shallow root can produce $1 \mathrm{~kg}$ dry biomass from 500-800 1 water (Barcsák et al., 1978), so the effect of drought for the production is very large. In addition, Hungarian turf is environmentally protected (Molnár-Csízi, 2015), so agrotechnics for growing production can hardly be applied.
Accordingly, new concepts have appeared in the turf utilization discipline (Szemán, 2006, and Harcsa, 2009). The so-called productive turf is suit for agricultural goals. The so-called abandoned turf is at the beginning of the ageing progress. With the progression of succession the fallow turf appears, where the valuable members of the turf force back because of the non-utilization, but they don't lack yet.

Degraded turf is when the production of the grass is not professionally utilized, so the worthless components of the turf spread in the coenoses. The incorrect utilization can have two types: overutilization, overloading with glazing animals, the non-glazed weed species appear in large quantities (Szente et al., 1998; Magyar, 2009). In the case of under-utilization succession progress can hazard the valuable turf components. According to Stefler et al. (2000) not only the overloading, but the lack of utilization cause degradation of the turf. Growing weeds on the turf and tillering cause this, which leads decreasing of the soil covering, overheated of the soil and degradational progress. According to Nagy (2001) on the non-utilized turf areas the mother hay is decrepit, budding is moderate, the large dipetalous weed species are spreaded. Falling off mowing starts reed growing on fields and forming forests on arid (Hansson and Fogelfors, 2000). The amount of flammable grass duff is significantly growing (Bakker-Berendse, 1999), and (Riser et al., 1995). Brockway et al. (2006) and Ónodi et al. (2008) also warn of the danger of the grass fires. Because of the improper utilization biodiversity of flora and fauna is (Barcsák et al., 1978), also foreign species appear, which causes collapsing of the natural (FerrerBroca, 1999). Da Ronche et al. (2002) investigated the consequences of skipping utilization on turf rich in species in North-East Italy and found that number of plant species decreased by $50 \%$. Tóth et al. (2002) examined fauna of natural turf on hard ground (like our experimental area) natural turf found that from glazing through mowing to non-utilization species richness is decreasing. Kahmen et al. (2002) and Isselstein et al. (2005) found that because of the lack of perfect treatment competitor species win space. According to Perevolotsky and Seligman (1998) under-grazing leads to ,green desert", the area becomes a wild, 
impenetrable bushy, which can easily catch fire. Margóczi (2003) botanically investigated natural turf on bare sand and found that for peserving this vegetation utilized and non-utilized areas are needed. According to Molnár-Csízi (2015), where there is grazing with shepherds, from well to well grazing can be a solution against bare areas around quarters and moorland on far steppes. Today, moorland on turf is a larger problem than baring due to the decreasing number of grazing livestock. Dense grass moor blocks germinating of seeds of valuable turf components, represses smaller species (fescue, testicle), wheat-grass spreads and weeds for example Daucus carota, succory can produce seeds. In addition, on non-utilized turf collared pratincole and field-lark are forced back. Jávor et al. (2000) determined that glazing extensive turf has not only economy profit, but inevitable field utilization.

An interest that our ancestors could utilize turf with moor. In the spring, grazing could begin earlier by utilizing newly growing grass on the moor from the previous year. Because of saving hay stocks grazing grass moor was utilized. If they wanted to utilize grass moor as a mowfield, at the end of the winter it was burnt by fast fire and ash usually provided a good mowfield (Baskay-Tóth, 1962). Nowadays burning and winter grazing are banned on turf.

\section{MATERIALS AND METHODS}

Our investigations were done in at the University of Debrecen, IAREF Research Institute Karcag on the turf number 01712/1 in 2017-18. This is a Natura2000 environmental protected area, so there is extensive meadow farming (1 mowing a year, then grazing aftergrass) form 1987. The grass association is AgrostiAlopecuretum pratensis. The altitude of the experimental area is $83 \mathrm{~m}$. The average amount of precipitation over 50 years is $503.4 \mathrm{~mm}$. The soil type is medium meadow Solonetz. Table 1 shows the results of laboratory tests of soil shapes from 0-10 cm depth before the experiment. The experiment started in 2009 with four treatments in three replicates. The area of the plots is $30 \mathrm{~m}^{2}$.

1. treatment: non-utilization from 2009 (,ancient turf' $\mathrm{A} / \mathrm{O})$

2. treatment: stem-crushing from 2009 , mulch stays on the area $(\mathrm{A} / \mathrm{M})$

3. treatment: mowing once a year (third decadal of May), removing phytomass (,one-side mowing” $\mathrm{A} / \mathrm{E})$

4. treatment: mowing (third decadal of May), removing hay, grazing aftergrass with sheep in August (,grazed-control” area, A/L)

Applied investigational methods:

- coenological monitoring

- measuring carbon-dioxide emission

- measuring soil moisture

- extended soil investigation
Table 1

Results of soil investigation before experiments

\begin{tabular}{|c|c|c|c|}
\hline Examined parameters & $\mathrm{A} / \mathrm{L} 1$ & $\mathrm{~A} / \mathrm{L} 2$ & A/L3 \\
\hline pH-value (KCl) & 4.7 & 4.5 & 4.8 \\
\hline $\mathrm{K}_{\mathrm{A}}$ & 53 & 58 & 51 \\
\hline All salinity soluble in water $(\mathrm{m} / \mathrm{m} \%)$ & 0.1 & $<0.02$ & 0.06 \\
\hline Carbonated lime $(\mathrm{m} / \mathrm{m} \%)$ & $<0.05$ & $<0.05$ & $<0.05$ \\
\hline Humus $(\mathrm{m} / \mathrm{m} \%)$ & 5.5 & 5.4 & 5.2 \\
\hline (nitrate+nitrite)-N ( $\left.\mathrm{mg} \mathrm{kg}^{-1}\right)$ & $<2.0$ & 4.9 & 8.5 \\
\hline Phosphorus pentoxide $\left(\mathrm{mg} \mathrm{kg}^{-1}\right)$ & 193 & 182 & 167 \\
\hline Potassium oxide $\left(\mathrm{mg} \mathrm{kg}^{-1}\right)$ & 393 & 519 & 383 \\
\hline Sodium $\left(\mathrm{mg} \mathrm{kg}^{-1}\right)$ & 784 & 119 & 511 \\
\hline Magnesium (mg kg-1) & 518 & 459 & 508 \\
\hline Sulphate-Sulphur ( $\left.\mathrm{mg} \mathrm{kg}^{-1}\right)$ & 3.8 & 18.3 & 19.7 \\
\hline Zinc $\left(\mathrm{mg} \mathrm{kg}^{-1}\right)$ & 4.4 & 4.4 & 4.5 \\
\hline Copper $\left(\mathrm{mg} \mathrm{kg}^{-1}\right)$ & 10 & 11 & 10 \\
\hline Manganese $\left(\mathrm{mg} \mathrm{kg}^{-1}\right)$ & 315 & 183 & 242 \\
\hline
\end{tabular}

Plant monitoring was done with quadrat method by Balázs (Balázs, 1949). It means that the size of the area used by a plant species on the monitored quadrat or area is determined with dominance value by $\left(\mathrm{D}_{\mathrm{B}}\right)$.

Carbon- dioxide concentration was measured with infrared gas analisator type Testo 535. Measuring process is the following: after determination of the measuring area, it is covered, incubation time is waited (30 min), then carbon-dioxide concentration is measured in barrels (Kovács, 2014). Data of the carbon- dioxide emission is calculated with the following formula:

$$
\mathrm{F}=\mathrm{d} *(\mathrm{~V} / \mathrm{A}) *\left(\mathrm{C}_{2}-\mathrm{C}_{1}\right) / \mathrm{t} * 273 /(273+\mathrm{T})
$$

where:

- $\mathrm{F}=\mathrm{CO}_{2}$-emission $\left(\mathrm{kg} \mathrm{m}^{-2} \mathrm{~h}^{-1}\right)$

- $\mathrm{d}=$ volume mass of $\mathrm{CO}_{2}\left(1.96 \mathrm{~kg} \mathrm{~m}^{-3}\right)$

- $\mathrm{V}=$ volume of the barrel above the sea level $\left(\mathrm{m}^{3}\right)$

- $\mathrm{A}=$ measured area $\left(\mathrm{m}^{2}\right)$

- $\mathrm{C}_{1}=\mathrm{CO}_{2}$ concentration at the beginning $\left(\mathrm{m}^{3} \mathrm{~m}^{-3}\right)$

- $\mathrm{C}_{2}=\mathrm{CO}_{2}$ concentration after incubation $\left(\mathrm{m}^{3} \mathrm{~m}^{-3}\right)$

- $\mathrm{t}=$ incubation time $(\mathrm{s})$

- $\mathrm{T}=$ air temperature $\left({ }^{\circ} \mathrm{C}\right)$.

Masuring soil moisture was done with an equipment type SMT-100, which measures dielectric conductivity of the soil and calculates the moisture in volume percentage.

Soil samples from depth $0-10 \mathrm{~cm}$ for soil investigations were analysed in the accredited laboratory of the University of Debrecen, IAREF Research Institute Karcag. Results are shown in another article.

\section{RESULTS AND DISCUSSION}

Experiments were performed in 2017-18. This study shows the results of the year 2018 . 
Results of coenological monitoring in 2018

Flora covering of the experimental area was determined with quadrat method by Balázs (Table 2).

Results of the coenological monitoring

\begin{tabular}{|c|c|c|c|}
\hline Treatment & Latin name & $\mathrm{D}_{\mathrm{B}}$-value & Covered area $(\%)$ \\
\hline \multirow[t]{7}{*}{ A/M1 } & Uncovered area & 0.5 & 1.5625 \\
\hline & Potentilla argentea & 0.5 & 1.5625 \\
\hline & Elymus repens & 0.5 & 1.5625 \\
\hline & Vicia tetrasperma & 0.5 & 1.5625 \\
\hline & Alopecurus pratensis & 16.0 & 50.0000 \\
\hline & Poa pratensis & 13.0 & 40.6250 \\
\hline & Rosa canina & 1.0 & 3.1250 \\
\hline \multirow[t]{8}{*}{$\mathrm{A} / \mathrm{M} 2$} & Lolium perenne & 0.5 & 1.5625 \\
\hline & Elymus repens & 0.5 & 1.5625 \\
\hline & Cirsium arvense & 1.0 & 3.1250 \\
\hline & Vicia tetrasperma & 0.5 & 1.5625 \\
\hline & Galium aparine & 0.5 & 1.5625 \\
\hline & Alopecurus pratensis & 18.0 & 56.2500 \\
\hline & Poa pratensis & 10.0 & 31.2500 \\
\hline & Rosa canina & 1.0 & 3.1250 \\
\hline \multirow[t]{8}{*}{ A/M3 } & Elymus repens & 1.0 & 3.1250 \\
\hline & Bromus pannonicus & 1.0 & 3.1250 \\
\hline & Cirsium arvense & 0.5 & 1.5625 \\
\hline & Vicia tetrasperma & 0.5 & 1.5625 \\
\hline & Galium aparine & 0.5 & 1.5625 \\
\hline & Alopecurus pratensis & 18.0 & 56.2500 \\
\hline & Poa pratensis & 10.0 & 31.2500 \\
\hline & Sonchus asper & 0.5 & 1.5625 \\
\hline \multirow[t]{3}{*}{$\mathrm{A} / \mathrm{E} 1$} & Potentilla argentea & 1.0 & 3.1250 \\
\hline & Alopecurus pratensis & 23.0 & 71.8750 \\
\hline & Poa pratensis & 8.0 & 25.0000 \\
\hline \multirow[t]{8}{*}{$\mathrm{A} / \mathrm{E} 2$} & Lolium perenne & 0.5 & 1.5625 \\
\hline & Potentilla argentea & 1.0 & 3.1250 \\
\hline & Elymus repens & 0.5 & 1.5625 \\
\hline & Cirsium arvense & 0.5 & 1.5625 \\
\hline & Vicia tetrasperma & 1.0 & 3.1250 \\
\hline & Trifolium retusum & 2.0 & 6.2500 \\
\hline & Alopecurus pratensis & 19.5 & 60.9375 \\
\hline & Poa pratensis & 7.0 & 21.8750 \\
\hline \multirow[t]{4}{*}{$\mathrm{A} / \mathrm{E} 3$} & Elymus repens & 1.0 & 3.1250 \\
\hline & Bromus pannonicus & 0.5 & 1.5625 \\
\hline & Alopecurus pratensis & 27.5 & 85.9375 \\
\hline & Poa pratensis & 3.0 & 9.3750 \\
\hline \multirow[t]{6}{*}{ A/Ö1 } & Uncovered area & 3.0 & 9.3750 \\
\hline & Elymus repens & 0.5 & 1.5625 \\
\hline & Alopecurus pratensis & 11.0 & 34.3750 \\
\hline & Poa pratensis & 7.0 & 21.8750 \\
\hline & Sonchus asper & 0.5 & 1.5625 \\
\hline & Rosa canina & 10.0 & 31.2500 \\
\hline \multirow[t]{7}{*}{ A/Ő2 } & Uncovered area & 4.0 & 12.5000 \\
\hline & Elymus repens & 3.0 & 9.3750 \\
\hline & Cirsium arvense & 0.5 & 1.5625 \\
\hline & Vicia tetrasperma & 1.0 & 3.1250 \\
\hline & Galium aparine & 0.5 & 1.5625 \\
\hline & Alopecurus pratensis & 15.0 & 46.8750 \\
\hline & Poa pratensis & 8.0 & 25.0000 \\
\hline \multirow[t]{4}{*}{ A/Ö3 } & Uncovered area & 2.0 & 6.2500 \\
\hline & Alopecurus pratensis & 15.0 & 46.8750 \\
\hline & Poa pratensis & 11.0 & 34.3750 \\
\hline & Rosa canina & 4.0 & 12.5000 \\
\hline
\end{tabular}

Table 2 shows that in case of mulch treatment there were Elymus repens, Vicia tetrasperma, Alopecurus pratensis, Poa pratensisspecies in every three plot. Because of mulch a bare area appeared in one of the plots.

In ,ancient turf" treatment because of grass moor the bare area appeared in every three plot. Because of abandoning to mow succession progress started, bushes, spreading of Rosa canina is significant. Our results prove the statements of Stefler et al. (2000).

In the monitored turf association in connection with covering proportion of the two dominant economically significant top grass, meadow-foxtail and meadowgrass (Figure 1), on the indicated area average covering of Alopecurus pratensis is $56.60 \%$, of Poa pratensis is $26.74 \%$. These figures show the stability of this turf association and the importance of ancient turf (Vinczeffy, 1993).

Figure 1: Covering percentage of Alopecurus pratensis and Poa pratensis

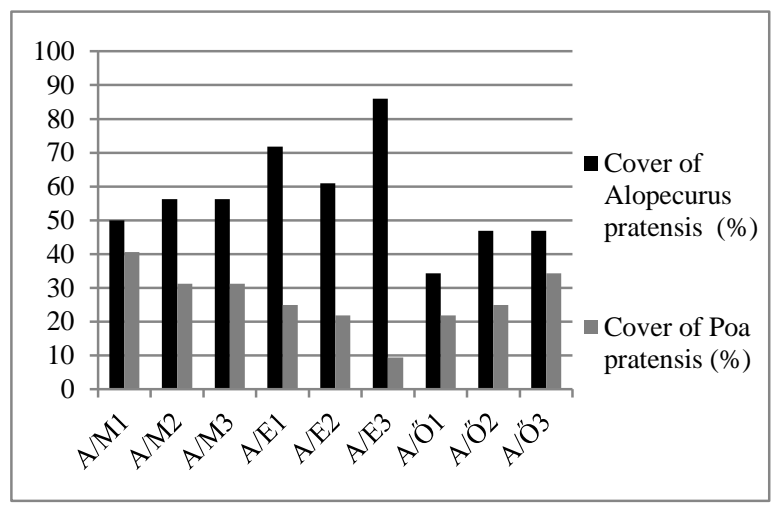

Results of measuring soil moisture in 2018

Table 3 shows soil moisture in each treatment. Values are higher in ,one-side mowing” and ,grazingcontrol" treatments than in ,mulch" and ,ancient turf" treatments. A week before taking samples the precipitation was $2.6 \mathrm{~mm}$, so moor and mulch absorbed a part of the precipitation, while in the other treatments it could leak into the soil because of the lack of moor phytomass.

\section{Results of measuring carbon-dioxide emission in 2018}

Measuring of carbon-dioxide was done with frame method of the Research Institution Karcag. Our experiences are the following: values are higher in „mulch” and ,ancient turf” treatments than ,one-side mowing" and "grazing-control” (Table 4).

Carbon-dioxide emission is influenced by the vegetation. We proved the statement of Kovács (2014), that on the areas covered with mulch and moor biological activity is higher because these can decompose and get into the soil as organic substances. 


\section{Results of measuring soil moisture in each plot}

\begin{tabular}{|c|c|c|c|c|}
\hline Treatments & 1.measurement $(\%)$ & 2.measurement $(\%)$ & 3.measurement $(\%)$ & Average soil moisture (\%) \\
\hline $\mathrm{A} / \mathrm{E} 1$ & 6.6 & 7.3 & 5.4 & 6.43 \\
\hline $\mathrm{A} / \mathrm{E} 2$ & 7.8 & 5.0 & 4.4 & 5.73 \\
\hline $\mathrm{A} / \mathrm{E} 3$ & 4.9 & 7.7 & 5.9 & 6.17 \\
\hline A/M1 & 6.6 & 4.5 & 4.7 & 5.27 \\
\hline $\mathrm{A} / \mathrm{M} 2$ & 3.9 & 5.0 & 7.2 & 5.37 \\
\hline $\mathrm{A} / \mathrm{M} 3$ & 3.9 & 7.4 & 4.1 & 5.13 \\
\hline A/Ö1 & 7.0 & 4.0 & 5.2 & 5.40 \\
\hline A/Ö2 & 4.8 & 6.0 & 5.5 & 5.43 \\
\hline A/Ö3 & 4.4 & 4.5 & 5.2 & 4.70 \\
\hline $\mathrm{A} / \mathrm{L} 1$ & 5.0 & 5.5 & 7.5 & 6.00 \\
\hline $\mathrm{A} / \mathrm{L} 2$ & 4.7 & 5.2 & 6.3 & 5.40 \\
\hline A/L3 & 5.8 & 6.2 & 6.4 & 6.13 \\
\hline Expected value & 5.45 & 5.69 & 5.65 & 5.60 \\
\hline Median & 4.95 & 5.35 & 5.45 & 5.42 \\
\hline Modus & 6.6 & 5 & 5.2 & 5.4 \\
\hline Scatter & 1.2823983 & 1.236901064 & 1.054427893 & 0.502611028 \\
\hline Variance & 1.6445455 & 1.529924242 & 1.111818182 & 0.252617845 \\
\hline Kurtosis & -0.935457 & -1.051512807 & -0.578954878 & -0.536926936 \\
\hline Skewness & 0.529015 & 0.483881461 & 0.375196196 & 0.086690898 \\
\hline Minimum & 3.90 & 4.00 & 4.10 & 4.70 \\
\hline Maximum & 7.80 & 7.70 & 7.50 & 6.43 \\
\hline Summary & 65.40 & 68.30 & 67.80 & 67.17 \\
\hline Number of pieces & 12 & 12 & 12 & 12 \\
\hline
\end{tabular}

Table 4

Values of carbon-dioxide emission

\begin{tabular}{cc}
\hline Treatment & $\mathrm{CO}_{2}$ emission $\left(\mathrm{g}^{*} \mathrm{~m}^{-2 *} \mathrm{~h}^{-1}\right)$ \\
\hline $\mathrm{A} / \mathrm{M} 1$ & 0.210 \\
$\mathrm{~A} / \mathrm{M} 2$ & 0.229 \\
$\mathrm{~A} / \mathrm{M} 3$ & 0.149 \\
$\mathrm{~A} / \mathrm{E} 1$ & 0.120 \\
$\mathrm{~A} / \mathrm{E} 2$ & 0.130 \\
$\mathrm{~A} / \mathrm{E} 3$ & 0.125 \\
$\mathrm{~A} /$ Ö1 & 0.231 \\
$\mathrm{~A} /$ Ö2 & 0.282 \\
$\mathrm{~A} /$ Ö3 & 0.213 \\
$\mathrm{~A} / \mathrm{L} 1$ & 0.111 \\
$\mathrm{~A} / \mathrm{L} 2$ & 0.097 \\
A/L3 & 0.061 \\
\hline Expected value & 0.16 \\
Median & 0.14 \\
Modus & - \\
Scatter & 0.06732986 \\
Variance & 0.00453331 \\
Kurtosis & -1.045255991 \\
Skewness & 0.292945818 \\
Minimum & 0.06 \\
Maximum & 0.28 \\
Summary & 1.96 \\
Number of pieces & 12 \\
\hline & \\
\hline & \\
\hline
\end{tabular}

\section{CONCLUSION}

Our study shows that, since the beginning of the experiment on the non-utilized area, succession (bushing) has started and bare areas have also appeared in these plots. The main species of the meadow-foxtail association (Alopecurus pratensis and Poa pratensis) cover $83.33 \%$ of the monitored ancient turf also 9 years after utilization. Measuring carbon-dioxide emission shows that on the plots covered by moor phytomass carbon-dioxide emission is higher. In the recent climatic change a key question is the value of carbon-dioxide emission of an agricultural area. 


\section{REFERENCES}

Bakker, J. P.-Berendese, F. (1999): Constraints in the restoration of ecological diversity in grassland and heathland communities. Trends in Ecology and Evolution. 14: 6368.

Balázs, F. (1949): A gyepek termésbecslése növénycönológia alapján. Agrártudományok. 1. 25-35.

Barcsák, Z.-Baskay-Tóth, B.-Prieger, K. (1978): Gyeptermesztés és hasznosítás. Mezőgazdasági Kiadó. Budapest: 32-103.

Baskay-Tóth, B. (1962): Legelő és rétmüvelés. Mezőgazdasági Kiadó. Budapest. 127-159.

Brockway, D. G.-Gatewood, R. G.-Paris, R. B. (2006): Restoring fireas an ecological process in shortgrass prairie ecosystems: initial effects of prescribed burning during the dormant and growing seasons. Journal of Environmental Management. 65: 135-162.

Da Ronche, F.-Ziliotto, U.-Scotton, M. (2002): Floristic composition Masscio del Monte Grappa (NE Italy) pastures in relation with de utilisation intensity. Multi Function Grassland.

Ferrer, C.-Broca, A. (1999): El bonimio agricultura-ganaderia en los ecosistemas mediterráneos. Actas de la XXXIX Reunion Cientifica de la Sociedad Espanola para el Estudio de los Pastos. 309-344.

Hansson, M.-Fogelfors, H. (2000): Management of a semi-natural grassland, results from a'5-year-old experiment in southern Sweden. Journal of Vegetation Science. 11: 31-38.

Harcsa, M.-Szemán, L.-Penszka, K. (2009): Telepített gyep szukcessziós folyamata az intenzív termesztéstechnológia felhagyása után. Tájökológiai Lapok 7(2): 409-416.

Isselstein, J.-Jeangros, B.-Pavlu, V. (2005): Agronomic aspects of biodiversity targeted management of temperate grasslands in Europe. Agricultural Research. 3: 139-151.

Jávor, A.-Kukovics, S.-Bálint, Cs. (20009: A gyepek termése és a juhok termelésének néhány összefüggése. Magyar Juhászat. 9 (6): 5.

Kahmen, S.-Poschlod, P.-Schreiber, K. F. (2002): Conservation management of calcareous grasslands. Boilogical Conservation 104: 319-324

Kovács, Gy. (2014): Mezőgazdasági hasznosítású talajok széndioxid- emissziójának vizsgálata Karcag térségében. PhD értekezés. Debrecen. 1-145.
KSH (2017): Mezőgazdasági Statisztikai Évkönyv. Budapest. 35.

Magyar, I. E. (2009): gyógynövényes gyep telepíthetősége. Gyepgazdálkodási módszerek növényállományra gyakorolt hatásának értékelése.. PhD értekezés. Gödöllő. 193.

Margóczi, K. (2003): Természetközeli gyepek regenerációja és restaurációja. Természetes állattartás 6. Debrecen. 50-56.

Molnár Zs.-Csízi I. (2015). Természetkímélő gazdálkodás szikeseken. 1-91.

Nagy, G. (2001): A gyephasználat és a vidékfejlesztés összefüggései. Gyepgazdálkodásunk helyzete és kilátásai. DGyN 17. Debrecen. 24-25.

Ónodi, G.-Kertész, M.-Botta-Dukát, Z.-Altbacker, V. (2008): Grazing effects on vedetation composition and on the spread of fire on open sand grasslands. Arid Land Research and Management. 22: 273-285.

Perevolotsky, A.-Seligman, N. G. (1998): Role of grazing in Mediterranean rangeland ecosystems. Bioscience 48: 10071017.

Ryser, P.-Langenauer, R.-Gigon, A. (1995): Species richness and vegetation structure in a limestone grassland after 15 year management with six biomass removal regimes. Folia geobotanica-Phytotaxonomica. 30: 157-167.

Stefler, J.-Nagy, G.-Vinczeffy, I. (2000): Különböző adottságú gyepek hasznosíthatósága húsmarhatartással. Állattenyésztés és Takarmányozás. 49/6: 495-496.

Szemán, L. (2006). Gyepgazdálkodási ismeretek. Gödöllő. 89.

Szente, K.-Nagy, Z.-Tuba, Z. (1998): Enhanced water use efficiency in dry loess grassland species grown at elevated air $\mathrm{CO} 2$ concentration. Photosynthetica 35: 637-640.

Tóth, Cs.-Nyakas, A.-Nagy, G.-Nan, Z. B. (2002): A comparison of two arid steppe vegetations from different geograpgical regions. Multifunction Grasslands. La Rochelle: 170-171.

Vinczeffy, I. (1993): Legelő- és gyepgazdálkodás. Mezőgazda Kiadó. 223-242. 